\title{
The 21st Century Scandal Must Be Prevented: Keynes vs Hazlitt
}

\author{
Ezra Davar \\ Independent Researcher \\ Email: ezra.davar@gmail.com
}

Received 15 February 2016; accepted 22 March 2016; published 25 March 2016

Copyright (C 2016 by author and Scientific Research Publishing Inc.

This work is licensed under the Creative Commons Attribution International License (CC BY).

http://creativecommons.org/licenses/by/4.0/

(c) (i) Open Access

\begin{abstract}
This paper shows that the return to Keynes's irrelevant and incorrect doctrines from his General Theory has begun; hence, it must be prevented. This paper shows: 1) Hazlitt's criticism of Keynes's concept of the investment multiplier is entirely correct, revealed and based on Keynes's fundamental flaw using throughout of the General Theory, namely replacement between cause and effect; 2) Hazlitt correctly criticized Keynes's extremely vague and incomplete definition of involuntary unemployment and full employment; however, he incorrectly stated that involuntary unemployment couldn't be equilibrium phenomenon; 3) Hazlitt successfully demonstrated that Keynes's monetary theory was confusing, incomplete, and even incorrect.
\end{abstract}

\section{Keywords}

Keynes, Hazlitt, Multiplier, Involuntary Unemployment, Money Theory

\section{Introduction}

This paper shows that the process for the 21 st century scandal, namely, return to Keynes's irrelevant and incorrect doctrines to reality from his General Theory governing not only thoughts of professional economists but also government leaders, unfortunately, is started; hence, it must be prevented.

More than 50 years ago, H. Hazlitt ${ }^{*}$ [1] [2] published two books; in the first, The Failure of "The New Economics", he asserted that "the best way to analyze the General Theory is to do so chapter by chapter" ([1], p. 9). Hazlitt's conclusion was:

I have been unable to find in it a single important doctrine that is both true and original. What is original in the book is not true; and what is true is not original. In fact, as we shall find, even much that is fallacious in the book is not original, but can be found in a score of previous writers ([1], p. 6).

\footnotetext{
"But whatever the full explanation of the Keynesian cult, its existence is one of the great intellectual scandals of our age.
} 
And

So I have found in Keynes's General Theory an incredible number of fallacies, inconsistencies, vaguenesses, shifting definitions and usages of words, and plain errors of fact ([1], $p .7)$.

It is clear that not all claiming of Hazlitt against Keynes's theory is correct, but majority of them required serious attention from the side who dealt with Keynes's approach, especially from the side of all Keynesians (post, neo, new). Unfortunately, this doesn't happen; the opposite is true: absolute ignorance (vide infra).

In the second book, The Critics of Keynesian Economics [2], the anthology, Hazlitt was the editor, and in Introduction he asked:

"Behind the triumph of the Keynesian philosophy and nostrums lies an intellectual mystery. How did it happen that a book so full of obscurities, contradictions, confusions, and misstatements was hailed as one of the great works of the Twentieth Century, and its author as a master economist?" ([2,]p. 9);

And concluded

"And the irony was that this heresy in turn became the intellectual fashion, which academic economists could ignore only at the cost of being themselves ignored, or challenge only at the cost of losing status.

But whatever the full explanation of the Keynesian cult, its existence is one of the great intellectual scandals of our age" ([2], p. 10).

In the Preface Hazlitt asserted that:

In the seventeen years since my anthology's original appearance, there has been a profound change in the academic reputation of Keynes's General Theory. It is no longer accepted as the new gospel. Professors of economics can openly declare themselves to be non-Keynesians and even anti-Keynesians, and still be treated with respect. In the serious press, the revolt has gone even further. Economic papers from the London Economist to The Wall Street Journal have published articles declaring that "Keynes Is Dead" ([2], p. 5).

But he added that:

On the other hand, it would be a profound mistake to conclude that criticism of Keynesian doctrine has already done its work, and that there is no reason to restate, republish, or add to it. It is true that the prevailing drift of academic opinion has changed, and that Keynesian doctrine no longer goes unchallenged. But there are still plenty of Keynesian and other inflationist in the academic community, and they are among its most articulate, publicized and prolific members (ibid. p. 6).

Hazlitt, unfortunately, undervalued the fact that several generations of economists were been so deeply poisoned by Keynes's irrelevant and incorrect theory to reality. In the process of working on this paper, I scanned more than 20 books written on Keynes's theory, especially after 2000 (The List of books see Appendix 1), and the result was amazing and very-very depressed, namely, no one of them not only has analyzed and tried to answer some Hazlitt's claiming against Keynes's theory but also even did not mention his books. Moreover, some economists have been blaming Hazlitt incompetent in economic theory, because he had not economic education. For example, Prof. P. Krugman recently asserted in his blog "Well, Hazlitt has been wrong about everything for more than 80 years, and is still regarded as a guru. Bad ideas, it appears, are extremely robust in the face of contrary evidence" [3].

Alas! Writings like this might be written only by the man who did not respect one and first of all himself. If even assume that Hazlitt is wrong about one of a concrete issue, this not means that he is "wrong about everything for more than 80 years"; and on the contrary, if a person is right in one issue, this not means that he/she is right in all issues, like Keynes. The same situation is also observed to relate L. A. Hahn's [4] and W. H. Hutt's [5] claim against Keynes's doctrines. It must be stressed that Krugman's statement "Bad ideas, it appears, are extremely robust in the face of contrary evidence" is much more fitting to Keynes's ideas from General Theory (vide infra).

Moreover, Krugman [6] also states that:

Those qualities allowed Keynes to lead economists, and the world, into the light-for The General Theory is nothing less than an epic journey out of intellectual darkness. That, as much as its continuing relevance to economic policy, is what makes it a book for the ages. Read it, and marvel. 
Special emphasis must be given to the valuation of Keynes's theory by the Soviet Economist E. Varga who is a critic, no less criticism than Hazlitt and who is absolutely unknown and totally ignored by Western economists. Varga wrote ([50], p. 305):

Keynes dealt with the superficial phenomena of capitalist economy. Paraphrasing Marx's words, we could call him the surface genius of bourgeois society. He does not pay the slightest attention of the basic categories of capitalist economy, the explanation of which takes up so much space in the writing the classics bourgeois political economy. He does not analysis categories such as commodity and money, value and surplus value, interest and entrepreneur's profit; he draws no distinction between the law of the movement of individual capital and that of the aggregate social capital, etc. Everything is clear to him, nothing poses a problem (italics original).

Varga summarized his very short, but very important paper as:

Keynes's popularity is explained not by his defence of capitalism but by the fact that he cloaks this defence by an aura of pseudo-scientificalness and a sterile criticism of capitalism. Keynes's popularity is explained not by his depth of knowledge, not by new ideas, but by eclecticism.

His popularity shows that monopoly capital cannot find a better answer to the insoluble contradictions of capitalism, the prelude to its historically inevitable doom. The dominance of Keynesian ideas is proof of the ideological bankruptcy of monopoly capitalism (italic original) ([50], p. 329).

Responsibility for such situation is generally laid on the economists of previous generation such as Blaug [8] [9], Barrow, Clower [10], Davidson [11], Krugman, Leijonhufvud [12], Lucas, Mankiw [13], Moggridge, Samuelson, Skidelski, Solow, Stiglitz [14] and so on; because despite that they are familiar with Hazlitt's books which have been absolutely ignored by them. At the same time, duty of the contemporary and next generation of economists will not trust blindly on the writing of economists' previous generation and investigate the origins independently to create his/her own opinion.

Despite that Hazlitt's book deserves contra analysis in detail, alike his analysis of General Theory, this paper examines only three central doubtful and incorrect issues of Keynes's General Theory ([1] [15]) because each of them is considered as the main factor of the revolutionary character of Keynes's theory by various economists ${ }^{1}$ and today relevant real economy: 1) investment multiplier; 2) involuntary unemployment; and 3) theory of money.

\section{Keynes's Investment Multiplier}

Hazlitt justly asserted that "We now come to the strange concept of 'the multiplier', about which some Keynesians make more fuss than about anything else in the Keynesian system. Indeed, a whole literature has developed around this concept alone" ([1], p. 135). Indeed, just P. A. Samuelson wrote about 10 papers about multiplier and what is result?

In the following Hazlitt reveals central flaw of Keynes's investment multiplier:

There are, in fact, so many things wrong with the "multiplier" concept that it is hard to know where to begin in dealing with them.

Let us try to look at one probable origin of the concept. If a community's income, by definition, is equal to what it consumes plus what it invests, and if that community spends nine-tenths of its income on consumption and invests one tenth, then its income must be ten times as great as its investment. If it spends nineteen-twentieths on consumption and invests one-twentieth, then its income must be twenty times as great as its investment. If it spends ninety-nine hundredths of its income on consumption and invests the remaining one-hundredth, then its income must be a hundred times its investment. And so ad infinitum (ibid.p. 139).

By this Hazlitt demonstrated the situation very exactly and he continued:

\footnotetext{
${ }^{1}$ Meade stated: "Thus the Keynesian theoretical revolution can be expressed in terms of the combination of his Multiplier theory with his Liquidity Preference theory" ([37], p. 87; see also Davidson [41], p. 172); and Robinson asserted "On the plane of theory, the revolution lay in the change from the conception of equilibrium to the conception of history; from the principles of rational choice to the problems of decisions based on guess work or on convention" ([42], p. 125). Klein stated: "The Keynesian theory is viewed in the following pages as a revolutionary doctrine in the sense that it produces theoretical results entirely different from the body of economic thought existing at the time of its development. The 'Revolution' discussed here is a revolution in thought, not in the economic policies of governments” ([43], p. 7).
} 
...given the fraction of the community's income that goes into investment, the income itself can mathematically be called a "function" of that fraction. If investment is one-tenth of income, income will be ten times investment, etc. Then, by some wild leap, this "functional" and purely formal or terminological relationship is confused with a causal relationship. Next, the causal relationship is stood on its head and the amazing conclusion emerges that the greater the proportion of income spent, and the smaller the fraction that represents investment, the more this investment must "multiply" itself to create the total income ([1], $p$. $139)$ !

Here Hazlitt rightly raised one of the crucial flaws of Keynes's theory characterized not only for the multiplier concept but also for majority issues, namely, replacement between cause and effect [15] [16]. For example Hazlitt asserted: "The whole of the General Theory might be described as an exercise in obfuscation, and the obfuscation begins at an early point ... Keynes is constantly reversing cause and effect, putting the cart before the horse" ([17], p. 44; see also pages: 98, 231, 259, 328, 333, 344, 418, 434, 435, and so on). Unfortunately, no one of Keynes followers have not been related such fundamental issues for all sciences, particularly for the economic science ([8] [18]-[20]).

Hazlitt rightfully stated that:

How marvelous is the Keynesian world! The more you spend the more you save. The more you eat your cake, the more cake you have. The less you save the more inducement you have to invest. But there is, perhaps, a flaw in this logic. Even Keynes has insisted that saving and investment must be equal. As you can only invest what you save, the less you save the less you are able to invest-no matter how great the "inducement" to invest. Moreover, it is not excessive saving that creates unemployment, but excessive wage-rates - wage-rates, that is, above the marginal-productivity point ([1], p. 375-376).

And

Keynes's own most extraordinary achievement was to overcome the beliefs of the "natural man" and at the same time to be wrong. For the natural man, unconfused by Keynesian economics, assumes in theory, if not in practice, that thrift is better than squandering; and Robinson Crusoe took it for granted that the propensity to work was more essential to his survival than the propensity to spend (ibid. p. 348).

Moreover, Post-Keynes economists have extended the multiplier conception and introduced, firstly, government purchases (spending) multiplier, when modern authors even favorably dwell upon the option of taxes multiplier [21] and Hoover states that "The expenditure multiplier is the intellectual basis for President Obama's stimulus package" [22].

Yet, Kamiryo, H. calculates the magnitude of "the Tax Multiplier" during 20 years (1990-2010) for 72 countries of the world [23].

Kamiryo asserts: "According to Davar Ezra (2010, 25), modern general equilibrium theory, sets investment the cause and sets national income the effect. The author's point at issue still differs from Davar Ezra's and clarifies a true story" ([23], p. 66).

This assertion of Kamiryo is erroneous: in my paper [16] it was shown that Keynes himself replaced the cause (national income) for effect (investment) in the first phase of investment process (vide supra) and it is not modern general equilibrium theory which makes the replacement, as Kamiryo asserts; because moderngeneral equilibrium theory does not used such terms as "national income" and "investment"; and finally, in my paper is written: for example: 1) the Keynesian multiplayer is based on the substitution of the cause (the national income) for the effect (investment); which yields an inadequate results; 2) Modern general equilibrium theory is based on the following assumptions: a) modern version of free goods conception and b) "Walras' Law" which assume that with an excess supply of a commodity, its price has to be zero; which is realistically absurd ([2] [16], p. 25).

His clarification is: "In the endogenous datasets, however, investment and income = output is two-way, and causes and results march simultaneously" ([23], p. 70).

This clarification is also incorrect, because according to Keynes's approach to the multiplier concept the whole process of investment generally consists of two phases. The first phase when investment is created; this is, investment (saving) is determinate; and therefore, the causal relation here moves from income to investment. This is when the increment in income causes an increment in investment. While the inverse relation means that in order to increase investment an analogous increment of income is required. 
In the second phase, investment is transformed into fixed capital and produces income in combination with other services (labour, land, money) and technology. So, in this phase, fixed capital (investment) is the determinant; and thus, the causal relation here moves from fixed capital to income. An increase of fixed capital causes an increment of income; while the inverse relation is equal to the next requirement: in order to increase income an increment of fixed capital is required.

Hence, they cannot be two-way, and causes and results march simultaneously. This means that in the first phase, income creates saving which is transformed into investment; hence, investment cannot create income. So in such a case there is no place for a multiplier, there may be only requirement [16].

Hazlitt went further and stated: "Optimism, income, consumption, and investment all interact, all mutually increase each other. But there is never any precise, predictable, mathematical relationship; there is never any fixed, or purely mechanical relationship among these elements".

In this whole process the concept of a fixed or predictable or predeterminable "multiplier" is never of any use ([1], p. 142; original emphasize).

This statement of Hazlitt is incorrect, because if Keynes's "multiplier" is not yields multiplication of income, but this not means that "there is never any precise, predictable, mathematical relationship; there is never any fixed, or purely mechanical relationship among these elements".

Replacement between the cause (national income) and the effect (investment) may also be interpreted in a backward (reverse) direction ([14] [16] [21]). Namely, in order that the effect (investment) would occur, it is required (necessary and sufficient condition) that the cause (national income) would be occurred before. It is necessary to emphasize that this does not mean that the effect (investment) churns out the cause (national income); i.e., there is no replacement between the cause and the effect; it is simply the fact that in the case when the causal nexus is known, the backward causality allows us to determine the required cause in order that certain effect would be produced.

On the other hand, Keynes's "multiplier" is the inverse of the marginal propensity to invest which indicates the required quantities of income for a unit of investment, when the marginal propensity of both does not change. This result is compatible with the result of the backward (reverse) causality in the determination of the investment multiplier. Therefore, the genuine meaning of Keynes's multiplier is tantamount to a requirement, and not to a multiplication. Hence, the requirement indicates on the required quantity of national income for the realization of one unit of investment (saving) when the marginal propensity to consume is constant. This means that an increase in consumption is not caused by the income that a new investment entails; except of an increase in investment and consumption which is produced by the income yields, by means of the available unemployed services (fixed capital and labor).

Hazlitt continued: but two criticisms of the "multiplier" remain to be made, and both are basic. In the first place, even granting all of Keynes's other peculiar assumptions, it is difficult to understand just why the multiplier (except by sheer assertion) should necessarily be the reciprocal of the marginal propensity to save. If the marginal propensity to consume is $9 / 10$, we are told, the multiplier is 10 . Why? How? ([1], p. 149) This criticism, in principle, is correct, but it will be incorrect to deny any using of the marginal (average) propensity to consume (vide supra).

And, Hazlitt added:

The final criticism of the multiplier that must be made is so basic that it almost makes all the others unnecessary. This is that the multiplier, and the whole unemployment that it is supposed to cure, is based on the tacit assumption of inflexible prices and inflexible wages. Once we assume flexibility in prices and wages, and full responsiveness to the forces of the market, the whole Keynesian system dissolves into thin air ([1], p. 151).

Indeed, this assumption is very crucial, but the "abstract method" means that theory reproduces real economic life only in a "simpler" form, in such way that theory has not be contradict reality, moreover, it has to be guided by reality. It is clear that abstract theory could never reproduce reality exactly, but theory must be as close as possible to it ([24] p. 1).

Hazlitt finished the criticism of Keynes's concept of the investment multiplier by the conclusion:

Keynes's investment "multiplier" is a myth. There is never any fixed, predictable "multiplier"; there is never any precise, predeterminable, or mechanical relationship between social income, consumption, investment, and extent of employment. An "equilibrium with unemployment" (to repeat) is a contradiction in terms. No 
investment "multiplier" can be calculated or even discussed except in relation to the extent of maladjustment or discoordination among prices and wage-rates, or to the state of business sentiment. Keynes's implied definitions of "saving" and "investment" constantly shift. He tacitly assumes that what is not spent on Marshall, A. (1930) The Pure Theory of Domestic Value, London: The London School of Economicsconsumption goods is not spent on anything at all. By "investment" he most frequently means government deficit spending financed by inflation.

His "multiplier" easily lends itself to a reduction ad absurdum ([1], p. 429-430).

To sum up, on the one hand, Hazlitt's criticism of Keynes's concept of the investment multiplier is entirely correct, revealed and based on Keynes's fundamental flaw using throughout of the General Theory, namely replacement between cause and effect ${ }^{2}$. But, at the other hand, Hazlitt incorrectly asserted that "there is never any precise, predeterminable, or mechanical relationship between social income, consumption, investment, and extent of employment". Because, as it was recently shown that Keynes's investment multiplier's genuine essence is a requirement, which indicates the quantity of national income needed to realize one unit of investment ([15] [16] [21]).

\section{Keynes’s Involuntary Unemployment}

Unemployment, one of the chronic afflictions of modern economics, will be cured only after accomplishing genuine theoretical definition accordingly to reality and on the basis of classical and neoclassical authors. Today there is absolute bewilderment in the using of the term "unemployment" and its various kinds because of two reasons: 1) the missing the line of demarcation between pure theory and applied theory; and 2) the unfounded supposition that no connection between Walras's and Keynes's approaches exists and they are completely opposite theories.

One group of economists using the term "unemployment" in the general sense without any specification of what kinds of unemployment it is; but in such case it is impossible to find compatible treatment for its curing. Another group of economist making differences between types of unemployment but there is not a common approach; each of them has been using his own interpretation and suggests different treatment.

Walras's theory seems to be "conveniently" characterized by full employment in services included labour. For example, Hayek asserted that: "But it does mean that we have to start where general economic theory stops; that is to say at a condition of equilibrium when no unused resources exist" ([25], p. 34); and "The existence of unused resources must be one of the main objects of our explanation" (ibid. p. 35) (see also [26], p. 58; [27], p. 17, and so on). However, this is incorrect since Walras's approach assumes that at equilibrium, there might be voluntary unemployment of services in Economies: Production, Capital Formation and Credit, and Circulation and Money, and unsold goods in an Exchange Economy ([28], p. 51-52 and [29]). One of the crucial reasons of the full employment interpretation of Walras's economy is the fact that Walras himself never discussed problems of employment, unemployment and used this term in his theoretical models. Nevertheless, careful analysis of the entire process of equilibrium establishment of Walras's approach enable to argue that there might be voluntary unemployment of services (including labor) and unsold goods in exchange economy. The "involuntary unemployment" is one of the central issues of Keynes's economic theory in his famous General Theory ${ }^{3}$. Moreover, it is Keynes's unique truly contribution, by the opinion of the author, to the Classical and Neoclassical economic theory. Unfortunately, Keynes's definitions of full employment, voluntary unemployment and involuntary unemployment are extremely vague and incomplete. Hazlitt rightly states:

\section{"It would be hard to imagine a definition more wordy, involved or obfuscate. I have read it an indefinite}

\footnotetext{
${ }^{2}$ Therefore, we cannot agree with Ahiakpor claiming that "However, Hazlitt's reduction of the multiplier argument to a simple arithmetical illusion has failed to diminish belief in Keynes's argument, perhaps because it appears to focus on the past or realized magnitudes $(Y / I=k)$. Hazlitt's critics easily may point out that the multiplier argument is about a projected change in income (and employment) in response to a change in investment spending, that is $\Delta \mathrm{Y}=\mathrm{k} \Delta \mathrm{Z}$ or k $=\Delta \mathrm{Y} / \Delta \mathrm{Z}$ " ([44], p. 765). In addition, together with fundamental methodological flaw of Keynes, replacement between cause and effect, Ahiakpor missing Hazlitt's additional argument against Keynes understands of the multiplier stating that "It is not production that determines incomes; it is not work that determines incomes; it is "the decisions to consume and the decisions to invest!" (H., p. 92; emphasizes in original), which is Ahiakpor's single argument: "The Keynesian multiplier story seems plausible only because both its proponents and previous critics have failed to ask the pertinent questions to help unmask its fundamental misconception of the economic process, especially the concurrent nature of production and subsequent exchange rather than a unidirectional one" ([44], p. 768).

${ }^{3}$ The notion "involuntary unemployment" was in use prior to Keynes both by English economists ([45], p. 19-20) and also by other countries economists [46]. But their notion differs from Keynes's notion.
} 
number of times, and as nearly as I can make out it means simply this: Men are involuntarily unemployed if an increase in prices relatively to wage-rates would lead to more employment" $([1], p$. 30); emphasis in original).

Keynes considered three kinds of unemployment: frictional, voluntary and involuntary and his definition of full employment includes "frictional" and "voluntary" unemployment: "This state of affairs we shall describe as 'full' employment, both 'frictional' and Voluntary' unemployment being consistent with 'full' employment thus defined" ([17], p. 15-16).

Therefore, Hazlitt's criticism on Keynes's full employment conception is justified:

The "contribution" of Keynes that his disciples most often insist upon as valid and "permanent" is the substitution of "full employment" as the goal of economic activity rather than the "maximum production" of the classical economists.

We shall ask here three main questions about "full employment": 1) Is it definable? 2) Is it attainable? 3) Is it — at all times and under all conditions — even desirable? ([1], p. 399).

Hazlitt continued:

In the General Theory, Keynes gives us two definitions, neither of which seems to have much relation to the other. On page 15 he gives an involved definition of "involuntary" unemployment which, as I have already tried to show ( $p .30)$, is invalid. From this he postulates a state of affairs in the absence of "involuntary" unemployment: "This state of affairs we shall describe as "full" employment, both "frictional" and Voluntary' unemployment being consistent with "full" employment thus defined" (p. 16). In other words, "full" employment is a state in which there can be both "frictional" and "voluntary" unemployment! Full employment is not full ([1], p. 401-402).

And, second definition of full employment:

Let's start again, this time with the definition on page 303 (GT):

We have full employment when output has risen to a level at which the marginal return from a representative unit of the factors of production has fallen to the minimum figure at which a quantity of the factors sufficient to produce this output is available. I confess I find it difficult to follow this jabberwocky; but I assume it implies that some sort of equilibrium has been reached. One is tempted to ask irreverently: Does this mean that Uncle Oscar has a job ([1], p. 402)?

It must be stressed that there is also third definition of full employment. Keynes as well as Walras, determined unemployment as the difference between the available quantity minus the employed quantity in equilibrium; and then discussed possible various kinds of unemployment. Keynes started his theory of employment in his book with the central statement: "The question, also, of the volume of the available resources, in the sense of the size of the employable population, the extent of natural wealth and the accumulated capital equipment, has often been treated descriptively. But the pure theory of what determines the actual employment of the available resources has seldom been examined in great detail" ([17], p. 4). This means that in the case that the available quantity is employed this means full employment.

Hazlitt continued:

When we speak of full employment, therefore, we would do better to use the term not as the Keynesian zealots use it, and not with any effort at an unattainable mathematical precision, but in a loose, common-sense way to mean merely the absence of substantial or abnormal unemployment.

If it be objected that this is not in fact a definition of full employment (and it is certainly not brimful employment), then I suggest that the term might be dropped entirely, and the term optimum employment used instead. This would have, among other advantages, that of reminding the user as well as his audience that employment is rather a means than an end, and that its optimum size is relative to other conditions or goals ([1], p. 405).

Is "full employment" attainable? Here even those who favor the goal begin to waver.

So when "full employment" is seriously discussed, it turns out to be less than full employment. And the desirability of "full employment at whatever cost" is gravely questioned ([1], p. 406).

And Hazlitt added: 
If we try to use the term with "scientific" or objective precision, "full employment" is not even definable. "Full employment at whatever cost" is not even desirable. It is best either to use the term in a loose common-sense way to mean the absence of abnormal involuntary unemployment, or to replace it by the term optimum employment. It is not an end in itself, but means to, or an accompaniment of, much broader ends, including mainly the maximization of consumer satisfactions. The economic objective of mankind, after all, is not more work but less (ibid.p. 435; emphasis in original).

This statement of Hazlitt may be is correct if "voluntary" unemployment is only considered according to Walras's definition (vide supra), then such definition of full employment might have certain reasoning, because in this case each individual is either employed or unemployed by his own wishes. But Keynes also included "forced unemployment", hence such definition of full employment is not only inconsistent with its practical definition, but also creates a mystified situation. But, Hazlitt's assertion that "full employment" is not even definable" is absolutely incorrect, because such definition of full employment fitting with its practical definition. So, this criticism of Hazlitt about Keynes's definition of full employment essentially is correct, despite of some inconsistency.

It is interesting to emphasize that despite that Hazlitt's main conclusion was that, in general, it is difficult to define full employment, it is not attainable and it is not desirable, he, at the same time, discussed about conditions to attain full employment:

What is necessary for full employment (using the word in a working, practical sense) is a proper relation among the prices of different kinds of goods and a proper balance between costs and prices, particularly between wages and prices. This functional balance will tend to exist when wage-rates are free and fluid and competitive, and not dictated by arbitrary union coercion. When this balance exists, full employment and maximized production and prosperity will tend to follow. When this balance does not exist, when wage-rates are pushed above the marginal product of labor, and profit margins are doubtful or disappear, there will be unemployment ([1], p. 426).

Post-Keynes economists have been discussing whether "involuntary unemployment" is equilibrium or a disequilibrium phenomenon. There are two opposite claims, those that claim it is a disequilibrium phenomenon ([1], p. 52; [10], p. 109; [30], p. 337-338) and those that claim that it is an equilibrium phenomenon ([11] [31], p. $567 ;[32]$, p. 1). In the latter case, the question is whether Keynes's equilibrium theory is compatible to Classical and Walras's one. A majority of economists assert that Walras's and Keynes's theory are different theories (for example Blaug, Leijonhufvud, De Vroey, and Davidson [33]), and unfortunately, only a few economists consider them to be related theories. Morishima asserted that "Indeed, it is the main purpose of this book (Walras' Economics-E.D.) to show how close Walras was to Keynes" ([26], p. 101 $)^{4}$. It is worthily recalling again here Chick's assertion that "It is doubtful, in fact, whether we would have got in such muddle over Keynes if we had understood Walras properly" ([34], 1978, p. 20).

Hazlitt was very harsh on the issue of equilibrium unemployment and repeatedly stated that "When Keynes speaks, therefore, as he does here and elsewhere, of 'equilibrium' with underemployment, he is talking nonsense. This is a contradiction in terms, like talking of an orderly chaos or a triangular circle. When Keynes speaks, in short, of an 'equilibrium' with unemployment, he is not really speaking of a position of equilibrium at all, but of something quite different" ([1], p. 52; emphasize original).

As it was recently shown [35] Keynes's involuntary unemployment derived from Walras's voluntary unemployment by means of changing of the characteristic of the aggregate supply curve (function) of labour. On the one hand, Walras's theory allows defining voluntary unemployment, despite of that post-Walras authors have been asserting that Walras economy is characterized by full employment. At the other hand, despite Keynes's vague and incomplete definition of full employment, voluntary unemployment and involuntary unemployment, it provides a theoretical framework for their definition. It was demonstrated that Keynes defined the following main characteristics of a general definition of involuntary unemployment: 1) It is an equilibrium phenomenon; 2) It may or may not exist, and, if it does, then equilibrium employment is less than the available quantity of the factor; 3) It may co-exist with voluntary unemployment.

It was shown that the kind of unemployment depends on the character of the original aggregate supply curve of labour. On the one hand, when the original aggregate supply function is a strongly increasing function, as in ${ }^{4}$ For example, Darity and Horn claim that "it is useful to demonstrate that Keynes's unemployment equilibrium could be a Walrasian equilibrium" ([47], p. 727). 
Walras's approach, there might be only voluntary unemployment, and its magnitude is the difference between the available quantity of labour and the equilibrium point. So, in such a case, an individual is unemployed according to his own wishes, because an equilibrium wage defined by free competition is less than a wage which he requires. But, at the same time it is incorrect to confuse Walras's voluntary unemployment with leisure. Moreover, unfortunately, some modern economists mistook Walras's voluntary unemployment with "involuntary unemployment" [36]. According to Walras's approach also might be considered "forced unemployment" which is the result of an intervention of external forces (government, monopoly, trade unions, and so on) into the market, and therefore, it is a disequilibrium phenomenon. Unfortunately, Keynes combined Walras's two types of unemployment, voluntary and forced, and called them "voluntary" unemployment. On the other hand, some economists interpreted Walras's forced unemployment as "involuntary unemployment" [30].

On the other hand, if the supply curve of labour isa weakly increasing, which means that the supply function may has a horizontal segment then there might be involuntary unemployment if the equilibrium point locates between boundary points of the horizontal segment, and the magnitude of involuntary unemployment is the difference between the right boundary point of the horizontal segment and an equilibrium point. So, in such a case, an individual is involuntary unemployed against to his own wishes, because an equilibrium wage defined by free competition is equal to a wage which he requires.

Therefore, Hazlitt's statement that Keynes's involuntary unemployment cannot be equilibrium phenomenon is erroneous.

To sum up, Hazlitt correctly criticized Keynes's extremely vague and incomplete definition of involuntary unemployment and full employment, however, incorrectly stated that involuntary unemployment cannot be equilibrium phenomenon.

\section{Money Theory}

The money theory has to be an anchor of Keynes's economic theory and his "main contribution"; and therefore, one of sources of Keynesian Revolution; in other words, it was Keynes's liquidity preference theory (LPT) of money that was the revolutionary aspect of Keynes's analysis ([11], p. 172). But unfortunately, Keynes's money theory is confusable, incomplete and even incorrect ([1] [15] [16]).

Hazlitt revealed many inconsistencies and fallacies in Keynes's monetary analysis, relevant to today's economics, which have never been discussed by Keynesians. It is difficult not to agree with one of Hazlitt's crucial accusations against Keynes's analysis that "One of the chief defects in Keynes's analysis, not only in the passage quoted above but throughout the General Theory, is his failure to adhere to any fixed meanings for his terms. He plays particularly fast and loose ..." ([1], p. 169); as it was demonstrated above when Keynes's two central concepts were discussed: investment multiplier and involuntary unemployment.

Hazlitt started this issue with the assertion:

We now come to three chapters and an appendix that it seems most convenient to treat as a unit. These are the chapters in which Keynes unfolds his famous concept of "liquidity-preference" as an explanation (in fact as the sole explanation) of the rate of interest, and in which he dismisses the alleged "classical" theory of the rate of interest as altogether inadequate and mistaken. We shall first take up the concept of liquidity-preference, to find what is wrong with it, and then see to what extent, if any, Keynes's criticisms of the "classical" theory of interest are warranted ([1], p. 186).

It must be stressed that some economists consider "liquidity-preference" as an expression of the revolutionary character of Keynes's theory. For example, Meade stated: "Thus the Keynesian theoretical revolution can be expressed in terms of the combination of his Multiplier theory with his Liquidity Preference theory" ([37], p. 87; see also [11], p. 172). But, Morishima stated that "It is true that Walras anticipated the Keynesian theory of liquidity preference by deriving the individual's demand for cash balances (encaisse desiree), as well as their savings, from utility analysis of consumer behavior" ([26], p. 205).

Indeed, Walras formulated, clearly and in detail, the cash balance for consumers and producers:

In a real operating economy, every consumer, whether landowner, labourer or capitalist, has at every moment a fairly exact idea of: 1) what stocks of final products be ought to have for his convenience and 2) what cash balance he ought to have, not only in order to replenish these stocks and make current purchases of consumer's goods and services for daily consumption while waiting to receive rents, wages and interest 
payable at fixed future dates, but also in order to acquire new capital goods ([38], p. 317). Finally, in the operation of the economy, every entrepreneur engaged in agriculture, industry or trade has at all times a fairly exact idea of: 1) what stocks of raw materials and manufactured products be ought to have for his particular volume of production and sales; and 2) what cash balances he ought be have for the replenishment of these stocks and for the purchase of productive services while waiting to be paid for the products he has sold ([38], p. 318).

The three terms ..., represent respectively cash in hands of consumers, cash in hands of producers, and money savings' ([38], p. 326, original emphasize).

Hazlitt rightly criticized Keynes for his confusing treatment of the liquidity-preference aspect. Starting from the analysis of Keynes's definition of liquidity-preference, Hazlitt asserted: "There are several odd things about this passage. Keynes begins by denying what nobody of sense asserts. Of course the rate of interest is not a return merely for 'saving or waiting as such.' But the saving or waiting is the necessary means to obtain the funds to be invested at interest" ([1], p. 187).

He continued by attacking Keynes's use of the motives for liquidity-preference:

'Now what are the motives for "liquidity-preference"? In separate chapters Keynes gives two different sets. In Chapter 13, "The General Theory of the Rate of Interest", he tells us:

The three divisions of liquidity preference which we have distinguished above may be defined as depending on 1) the transactions-motive, i.e., the need for cash for the current transaction of personal and business exchanges; 2) the precautionary motive, i.e., the desire for security as the future cash equivalent of a certain proportion of total resources; and 3) the speculative motive, i.e., the object of securing profit from knowing better than the market what the market will bring forth (Hazlitt [1], 1959, p. 170).

But in Chapter 15, "The Psychological and Business Incentives to Liquidity", Keynes gives us a further breakdown of the "transactions-motive" into the "income-motive" and the "business-motive" ([17], p. 189).

However, in the following, different motives were merged:

Let the amount of cash held to satisfy the transactions- and precautionary-motives be $\mathrm{M}_{1}$, and the amount held to satisfy the speculative-motive be $\mathrm{M}_{2}$. Corresponding to these two compartments of cash, we then have two liquidity functions $\mathrm{L}_{1}$ and $\mathrm{L}_{2}$. $\mathrm{L}_{1}$ mainly depends on the level of income, whilst $\mathrm{L}_{2}$ mainly depends on the relation the current rate of the interest and the state of expectation. Thus $\mathrm{M}=\mathrm{M}_{1}+\mathrm{M}_{2}=\mathrm{L}_{1}(\mathrm{Y})+\mathrm{L}_{2}(r)$, ([17], p. 199).

Here Keynes proposed two erroneous assumptions. First, Keynes merged the transaction-motive, which already represents a combination of the income-motive and the business-motive, with precautionary-motive. This eliminates the difference between two types of money: money as a medium of exchange, a measure of value and a store of value (the money commodity-numéraire) and money for circulation (the money commoditynuméraire, or fiat money), and therefore, consequently, the difference between two various prices for money commodity are also eliminated. This is the main reason that in modern economics only fiat money is used.

Second, Keynes asserted that $\mathrm{L}_{1}$ - liquidity function of the amount of cash to satisfy the transactions-and precautionary-motives $\left(\mathrm{M}_{1}\right)$ depends mainly on the level of income $\left[\mathrm{M}_{1}=\mathrm{L}_{1}(\mathrm{Y})\right]$. Here, Keynes assumed that the liquidity function is the inverse function of the income function. Keynes used this approach very frequently, for example for the employment function, which is determined as the inverse function of the aggregate supply function ([17], p. 280; Hicks also used this approach in his famous IS-LM model). However, the inverse function exist only for the function of one variable with specific properties, namely, the function must be either strictly increasing or strictly decreasing function. Yet, the income function is the function for many variables (prices and available quantities for all categories - goods, factors of production (labour. fixed capital and money) and so on). Therefore, the assumption that the income function as the function of one variable, ones of money, ones of available quantities of either labour or fixed capital, is incorrect. What means that the liquidity function for the transactions- and precautionary-motives $\left[\mathrm{M}_{1}=\mathrm{L}_{1}(\mathrm{Y})\right]$ as the inverse function of the income function is not exist.

In the following Keynes surprisingly states that "In the static society in which for any other reason no one feels any uncertainty about the future rates of interest, the Liquidity Function $\mathrm{L}_{2}$, or the propensity to hoard (as we might term it), will always be zero in equilibrium. Hence in equilibrium $M_{2}=0$ and $M=M_{1}$ " ([17], p. 209). But, this means that the rate of interest, crucial determinants, have disappeared in the equilibrium state! Keynes continues: “...so that any change in $\mathrm{M}$ will cause the rate of interest to fluctuate until income reaches a level at 
which the change in $M_{1}$ is equal to the supposed change in $M$. Now $M_{1} V=Y$, where $V$ is the income-velocity of money as defined above and $\mathrm{Y}$ is the aggregate income. Thus if it is practicable (our emphasis) to measure the quantity, $\mathrm{O}$, and the price, $\mathrm{P}$, of current output, we have $\mathrm{Y}=\mathrm{OP}$, and, therefore, MV = OP" ([17]. p. 209).

It is interesting that Hazlitt substituted Keynes's term "liquidity-preference" for the term "cash preference" asserted that "I do not think that either term is helpful or necessary; they throw considerably more confusion, and considerably less light, on the condition to be analyzed than the traditional terms that Keynes rejects. But as between the two, cash preference is much to be preferred to liquidity-preference, not only because it is less vague, but because it does not, like liquidity-preference, make Keynes's doctrine self-contradictory” ([1], p. 193). By this Hazlitt was close to Walras's "cash balance".

Hazlitt rightly criticized Keynes's understanding of the functions of money, asserting that "This is an extraordinary perversion of classical doctrine. The most usual statement in the orthodox economic textbooks is that money serves first of all the function of a medium of exchange. And according to some economists, this function includes and subsumes all its other functions such as 'money of account', 'standard of value', and 'store of value' - which are merely the qualities of a satisfactory or ideal medium of exchange” ([1], p. 191).

Hazlitt also rightly attacked Keynes's theory of interest rate, and stated that 'Now Keynes's theory of interest is a purely monetary theory. Keynes, in fact, ridicules all theories of interest that bring in 'real' factors" ([1], p. 193); and asserted that' This is to throw out cavalierly not only Marshall but practically all the "classical" and "neo-classical" economists - in fact, all the economists who have made any contribution to the subject since the Middle Ages. Interest, of course, is normally paid in money. But so is rent; so are profits; so are prices; and so are wages. They all, like interest, "belong to a monetary economy". On this reasoning we would take no account of real factors whatever but throw the analysis of everything into the books devoted purely to money' ([1], p. 194); and "Keynes's fallacy consists in assuming that because monetary factors can be shown to affect the rate of interest, "real" factors can safely be ignored or even denied" ([1], p. 196); and "Few persons, after reading Fisher, can fail to find Keynes's discussion of interest superficial, haphazard, and even amateurish" ([1], p. 206).

Hazlitt correctly formulated the equilibrium conditions, albeit not complete, in order to define interest rate, stating that

If the market interest rate, for example, was in "complete" equilibrium, here are some of the things that would have to be equated:

1) The supply of, with the demand for, capital (i.e., the supply of savings with the demand for investment);

2) The price of capital instruments with their cost of production;

3) The income from capital goods with their price and their cost of production;

4) The "marginal yield of capital" with the rate of time discount (time-preference);

5) The supply of loanable (monetary) funds with the demand for loanable funds ([1], p. 207).

Hazlitt claimed that some aspects of the interest rate theory which were correctly formulated by Keynes were discovered by his predecessors, asserting that:

Nor would he have been the first to discover, if he had discovered it, that both sets of influences, real and monetary, had to be recognized and reconciled in any complete theory of interest. That glory belongs to the Swedish economist Knut Wicksell. The great contribution which Wicksell made to interest theory was to reconcile the "real" theories of interest as developed by the classical economists and amended by Jevons and Böhm-Bawerk, with what actually happens to interest rates in the day-to-day money market as the banker or the security investor confronts it. The real factors act through the monetary factors. Wicksell's really general theory of interest (real-cum-monetary) was carried further by Irving Fisher and receives its most mature exposition in the work of Ludwig von Mises ([1], p. 213).

And

This is a brief, oversimplified, and inadequate description of the process. But it is sufficient to show that everything that is true in the Keynesian monetary theory of interest was already recognized by Wicksell, Fisher, Mises, Hayek, and others before Keynes wrote ([1], p. 214-215).

One of the central flaws of Hazlitt, as with the majority of the 20th century economists, was misunderstanding and misinterpreting of Walras's theory, especially money theory. Walras's major and unique contribution is the integration of his money theory into his general equilibrium theory which enabled him to consider the real eco- 
nomic and financial sector as one integrated system. Schumpeter stated that "In the same sense in which it is true to say that he (Walras-E.D.) created economic statics, the modern theory of economic equilibrium, it is also true to say that he created the modern theory of money. In fact, his theory of money and credit is simply part of this general theory of economic equilibrium" ([39], p. 1082).

Classics' and Walras's distinction between money commodity (numéraire) and money (for circulation) have been the cause of a certain amount of confusion. For example, there are many economists, who claim that Walras's GET is only a barter exchange economy and money does not play any role. Majority of authors identifying fiat money with money and modern theory used only fiat money. I addition, if we take into account the fact that the contemporary world economy is governed by fiat money, the issue of the relationship between numéraire and money becomes crucial not only in order to understand Walras's monetary theory, but also to understand modern money theory as in general.

Keynes, like Classics and Walras, considered two types of money: money commodity (numéraire) and money. However, Keynes used the wage-unit as a numéraire, whilst Walras used precious metal (gold and silver). But using the wage-unit as a numéraire is very doubtful because of its determination: "the money-wage of a labour-unit we shall call the wage-unit" ([17], p. 41). But, in our opinion, in fact Keynes as well as Marx, used as a numéraire the labour-unit, which was used as a measure of the quantity of employment [17] [40].

In such a case there are two crucial problems. Firstly, whether labour might be used as a numéraire since in equilibrium state might be an unemployed part of labour? Secondly, labour is not homogeny and assuming that labour might be used as a numéraire then the question is what kind of labour is would be used? Keynes suggested using "an hour's employment of ordinary labour as our unit and weighting an hour's employment of special labour in proportion to its remuneration; an hour of special labour remunerated at double ordinary rates will count as two units" ([17], p. 41).

As Hazlitt correctly asserted: "Now to say that the wage-unit is the essential standard of value is to say that the price in dollars, and moreover the average price in dollars, of a heterogeneous good or service is the "essential standard of value", and not the dollar in terms of which the price is expressed. For the "wage-unit", let us remember, is the "money-wage" of "an hour's employment of ordinary labor" ([1], p. 41).

It is necessary to stress that, unfortunately, this is not as easy as Keynes described it. This is well known as an unsolved problem of the reduction of labour since Marx, who used the term "abstract labour" and invested, in vain, huge energy to determine a unit of such labour. These problems are very acute when we consider a model including other services' prices, such as the rent of land, the price of fixed capital' service and the interest rate of money. Keynes factually discussed the model with regards to one service [15] — Labour and but at the same time he discussed the problem of the marginal efficiency of capital and interest rate of money. This was in textual form and was not included in the model. Moreover, Marx used "abstract labour" only for the specific theoretical problem, namely for the problem connected to the Exploitation of the Workers' Class. However, when Marx discussed problems of real economics he used only money measurement, while, Keynes used "wage-unit" for the real economic problem if we assume that Keynes's economy is a real economy.

In addition, the use of labour (or wage-unit) as a numéraire is problematic, if impossible, because the numéraire is a basic component of the monetary system and it is used for all functions of money: exchange (transaction), measurement and storage. At the same time, it is necessary to note that Keynes used the term "gold standard" in the text of General Theory, but he never discussed the relationship between the wage-unit, the gold standard and paper money.

Keynes never discussed problem of relationship between money commodity and fiat money which is one of central issues of money theory. Moreover, Keynes in the following gave up money commodity and discussed only money for circulation but he did not used the term "money for circulation". Hazlitt, unfortunately, accepted this situation and continued its analyses.

At the same time, Hazlitt correctly understood the essence of general equilibrium theory; like Walras and Marx, he asserted that: Paraphrasing and reversing Grover Cleveland's famous aphorism, we may say regarding economic equilibrium that it is a concept that confronts us, not a condition. Yet this concept is not unrelated to reality. It is a limiting notion. There is always a tendency toward equilibrium. An economy can get stuck for a long period at a point of unemployment, as a clock can get stuck if someone puts chewing gum in the works. But in neither case should the result be called "equilibrium" ([1], p. 252).

Hazlitt rightly criticized Keynes stated that:

There is, finally, no such functional relationship between the level of interest and the level of employment 
as Keynes assumes (He offers, in fact, neither statistical nor plausible logical grounds for this assumption). The really significant relationship, which Keynes persistently ignores or denies, is that between the level of wages and the level of employment.

The rate of interest and the level of employment are related in any actual situation only in the sense that there is some interconnection among all economic phenomena (ibid.).

And

We have already seen that Keynes had a false theory of interest. We shall soon see that he had also a false theory of wage-rates, a false theory of money and credit, and a false theory of prices ([1], p. 262).

Yet

...if the price of any commodity or service is kept too high (i.e., above the point of equilibrium) some of that commodity or service will remain unsold ([1], p. 263).

Hazlitt correctly attacked Keynes's vague additional interpretation of the essence of money asserted that:

"In discussing money, for example, he tells us in italics: 'The importance of money essentially flows from its being a link between the present and the future' ( $p$. 293). And again: 'Money in its significant attributes is, above all, a subtle device for linking the present to the future' ( $p .294)$. Now I should say, 'on the contrary, that the importance of money flows essentially from its being a medium of exchange, and that its most significant attribute is that it functions as the medium of exchange' ([1], p. 294); and 'In modern marginal theory, prices and costs mutually determine each other; there is no one-way causation. Wicksell, endorsing the mathematical formulation of Walras, put it forcibly"' ([1], p. 297).

Hazlitt also claimed about Keynes's usual twofold relation to the quantity theory of money, stressing that: "Keynes is right in not accepting 'the Crude Quantity Theory of Money', but his treatment of the whole subject is superficial and confused" ([1], p. 298); and "An increase in the 'velocity-of-circulation' of money, therefore, does not necessarily mean (other things remaining unchanged) a corresponding or proportionate increase in 'the price-level'. An increased 'velocity-of-circulation' of money is not a cause of an increase in commodity prices; it is itself a result of changing valuations on the part of buyers and sellers. It is usually a sign merely of an increase in speculative activity. An increased 'velocity-of-circulation' of money may even accompany, especially in a crisis at the peak of a boom, a jail in prices of stocks or bonds or commodities" ([1], p. 301).

Hazlitt justly indicated Keynes's vague and even incorrect use of mathematics in General Theory:

Do such symbols and manipulations, however, in fact usually serve this purpose? Or do they not much more frequently deceive the writer who uses them (and many of his readers) into supposing that he has discovered something; that it will now be easy (or at least possible) to ascertain and substitute real numerical values for his algebraic symbols and hence determine real relationships or make precise predictions that apply to the real world ([1], p. 306)?

And

Keynes's mathematical equations on pages 304-306 are peculiarly suspect because they are all concerned with "elasticities" of prices, "wage-units", output, "effective demand", employment, etc. Some of these concepts (e.g. "output") are obviously too heterogeneous and hazy to be capable of statement in useful or valid mathematical form ([1], p. 307).

Some "critics" of Hazlitt unjustly stated that as if Hazlitt denied using mathematics in his economics theory (vide infra).

Hazlitt rightfully claimed that: "It is impossible to treat this final section (Chapter 21-E. D.) as serious economics. It is designed to prove: 1) that it would be harmful or dangerous to reduce almost any wagerate and 2) that it would be beneficial to reduce almost any interest rate" ([1], p. 312).

Hazlitt also rightly asserted that Keynes's attempt to manipulate the interest rate and wages independently from other parts of the entire economy is erroneous:

All this is, of course, nonsense. The rate of interest is a market price like any other market price. It is as flexible (on new loans) as any other price (as any historic comparisons will show) and much more flexible over short periods (especially in the downward direction) than wage-rates ([1], p. 317). 
And

Interest rates are related to other prices and are constantly adjusting to other prices, as other prices are to them. Wage-rates are related to other prices and (when not fixed by government or union coercion) are constantly adjusting to other prices, as other prices are to them. When both adjustments are right, when there is full price, wage, and Interest rate coordination, there is full employment and maximum balanced production. But Keynes treats both interest rates and wages as if they were completely outside of the price system, or at least as if they ought to be. Government must constantly step in to keep up wage-rates and to push down interest rates ([1], p. 318-319).

Hazlitt correctly indicated that despite the fact that the marginal efficiency of capital is one of the central variables in the Keynesian system, its definition by Keynes is vague and unclear; moreover, Keynes gave only its verbal concept because Keynes's macro model includes only one factor, namely labour. So, Hazlitt asserted:

Now, as we have already pointed out, "the marginal efficiency of capital", like most of the key Keynesian terms, is vague, and is used by Keynes in several different senses. At one time it seems to mean the actual present yield of capital assets; at another time the expected future yield of specific capital assets; and at still another time it seems to mean merely the outlook for business profits, regardless of the specific return to a specific capital asset ([1], p. 319-320).

And

In sum, Keynes's explanation of the crisis as a sudden collapse of the marginal efficiency of capital is either a useless truism or an obvious error, according to the interpretation we give the phrase "the marginal efficiency of capital" ([1], p. 322).

Hazlitt attacked Keynes's treatment of crises which is, unfortunately, widely used in today's practices. Hazlitt stated:

Keynes recommends two main remedies. One is deficit spending (sometimes euphemistically called government "investment") ([1], p. 421).

The other main Keynesian remedy for unemployment is low interest rates, artificially produced by "the Monetary Authority" ([1], p. 422).

On the basis analysis of USA economics Hazlitt concluded (ibid. p. 421-424):

We must conclude at least that neither deficit spending nor cheap money policies are enough by themselves to eliminate even prolonged mass unemployment, let alone to prevent unemployment altogether ([1], $p .424$ original emphasize).

Therefore, Hazlitt's comparison of Keynes's remedies to mercantilists is correct:

Practically all the Keynesian remedies, then-especially arbitrarily holding down interest rates and inflating the currency — were known to and practiced by the mercantilists of the seventeenth century and earlier, by Keynes's own admission.

The "new economics", in brief, turns out to be merely the exhumation of ancient and exploded fallacies ([1], p. 348).

Hazlitt ended his writing with the following statement:

We have been forced to be critical, and sometimes harshly so, about every chapter of Keynes's General Theory and every leading proposition it contains. I am sorry for this for more reasons than one ([1], $p$. 391).

And

Keynes was a brilliant man. Much of what he wrote he wrote with tongue-in-cheek, for the pleasure of paradox, to épater le bourgeois, in the spirit of Wilde, Shaw, and the Bloomsbury circle. Perhaps the whole of the General Theory was intended as a huge (400-page) joke, and Keynes was appalled to find disciples who took it all literally.

Wit and satire are dangerous weapons when not used in the service of good sense ([1], p. 398). 
To sum up, Hazlitt successfully demonstrated that Keynes's monetary theory is confusing, incomplete, and even incorrect.

\section{Conclusions}

This paper has shown that the return to Keynes's irrelevant and incorrect doctrines from his General Theory has begun; hence, it must be prevented.

For this purposes this paper examines only three central doubtful and incorrect issues of Keynes's General Theory among a lot of flaws Revealed by Hazlitt, because each of them is considered the main factor of the "revolutionary" character of Keynes's theory by various economists: 1) investment multiplier; 2) involuntary unemployment; and 3) theory of money.

It was shown that:

1) On the one hand, Hazlitt's criticism of Keynes's concept of the investment multiplier is entirely correct, revealed and based on Keynes's fundamental flaw using throughout of the General Theory, namely replacement between cause and effect. But, at the other hand, Hazlitt incorrectly asserted that "there is never any precise, predeterminable, or mechanical relationship between social income, consumption, investment, and extent of employment". Therefore, the fact that almost all Keynesians (post, new, now) have been ignored Hazlitt's criticism of Keynes's investment multiplier has been yielding tremendous harm not only from the theoretical issue, but also in policy making and economic education;

2) Hazlitt correctly criticized Keynes's extremely vague and incomplete definition of involuntary unemployment and full employment; however, he incorrectly stated that involuntary unemployment couldn't be equilibrium phenomenon;

3) Hazlitt successfully demonstrated that Keynes's monetary theory is confusing, incomplete, and even incorrect.

\section{Epilogue}

There are two reviews on Hazlitt's book that might be the explanation one of the central reasons why there is absolutely ignorant from it. A. Lerner wrote two pages review and contrived to introduce so many non-objective mockeries and cynicisms that are enough for several books. J. P. McKenna's review is a little moderate; however, its evaluation of Hazlitt's book is also inadequate.

I did not refer their "evaluation" in the text of the paper, but below the readers might find them and I believe they make their judgments about "value" and "contribution" of such reviewers.

Quotation from Lerner's reviewer:

1) In the present book Hazlitt does not write the second lesson because he has not learned it. It is the most depressing book. Reading this book, it feels like grading a hundred examination papers by intelligent students who all write interestingly and clearly; who have all listened very carefully, read much and worked very hard, but who must, nevertheless, all be given an "F" because everyone has missed every point in every question in the examination ([48], p. 234);

2) He sees these because of a fundamental misunderstanding in a Kafkaesque night-mare of discussion at cross purposes (ibid.);

3) Given the strain that this must have imposed, one can understand his charging Keynes with irresponsibility, verbal tricks, perverse logic, howling nonsense, willful blindness, totalitarian objectives, and intellectual dishonesty (ibid.);

4) "...much easier than the heavily handicapped safari through the Keynesian jungle reported in his book" ([48], p. 235);

5) It is the traumatic shock at discovering that even Keynesian economics may not be enough to give us full employment with price stability that bears a large part of the responsibility for the current regression from Keynesian to pre-Keynesian economics and for the balancing of the budget being given a higher priority by our government than the building of a viable noncommunist world. It is the threat of having to learn lesson three that is responsible for the regression from lesson two to ritualistic reciting of lesson one and for the popularity of books like Hazlitt's in places like the Wall Street Journal (ibid.).

Quotation from McKenna's reviewer:

1) Hazlitt properly objects that the General Theory is quite special, applying only to conditions of unemployment. Yet he ignores this specialty repeatedly, accusing Keynes of error and proving the error by the assumption of relatively full employment ([49], p. 189); 
2) Thus Hazlitt proves that interest rates cannot be held below the natural rate by monetary policy because rising prices would force interest rates back up (ibid);

3) Again, he objects that government spending might only encourage unions with excessive wage rates to demand even higher wages and the new spending may even lead to a decrease in employment (even under full employment, this last conclusion would be justified only with rather strangely shaped labor-supply curves) (ibid.);

4) On its statements of fact, Hazlitt's book is somewhat better documented than Keynes's, but could have used much more. As a rebuttal of Keynes, however, the documentation is grossly unfair; it takes Keynes to task because his statements do not correspond to the data of the last twenty years (ibid.);

5) Hazlitt opposes the use of mathematical formulations on the ground that economic relations are not sufficiently precise to permit their use. This is hardly an answer, for good verbal economics should be precise as well. Surely the initial mathematical formulations by Keynes have had a tremendous impact upon attempts to make these relationships more precise by more sophisticated techniques. The important question is not about perfection, but about whether the approximation is sufficiently accurate to add anything to our understanding ([49], p. 190);

6) Although Hazlitt clears up many minor points in the General Theory, his analysis of the major ones is completely unsatisfactory. In short, those who agree with Hazlitt's preconceptions will find many excuses for their views; those seeking enlightenment must look elsewhere ([49], p. 190).

\section{References}

[1] Hazlitt, H. (1959) The Failure of the "New Economics". Van Nostrand, Princeton.

[2] Hazlitt, H. (1960) The Crisis of Keynesian Economics. Irvington-on-Hudson, New York.

[3] Krugman, P. (2013) The Paradox of Flexibility. 16 July, the New York Times. http://krugman.blogs.nytimes.com/2013/07/16/the-paradox-of-flexibility/? php=true\& type=blogs\& $\mathrm{r}=0$

[4] Hahn. L.A. (1949) The Economics of Illusion. Squier Publishing Company, Inc., New York.

[5] Hutt, W.H. (1963) Keynesianism-Retrospect and Prospect: A Critical Restatement of Basic Economic Principles. Henry Regnery Company, Chicago.

[6] Krugman P. (2006) Introduction to the General Theory of Employment, Interest, and Money. By John Maynard Keynes, Palgrave Macmillan. https://notendur.hi.is/gylfason/KrugmanonKeynes.pdf

[7] Varga, E. (1968) The Reason for the Popularity of Keynesians Theories. In Politico-Economic Problems of Capitalizm, Progress.

[8] Blaug, M. (1993) Second Thoughts on the Keynesian Revolution. HOPE, 23, 171-192.

[9] Blaug, M. (1996) Economic Theory in Retrospect. 5th Edition, Cambridge University Press, Cambridge.

[10] Clower, R.W. (1965) The Keynesian Counterrevolution: A Theoretical Appraisal. In: Hahn, F.H. and Brechling, F.P.R., Eds., The Theory of Interest Rate, Macmillan, London, 103-125.

[11] Davidson, P. (1967) A Keynesian View of Patinkin's Theory of Employment. The Economic Journal, 77, 559-578.

[12] Leijonhufvud, A. (1968) On Keynesian Economics and the Economics of Keynes. Oxford University Press, New York.

[13] Mankiw, N.G. (1997) Macroeconomics. 3rd Edition, Worth Publishers, New York.

[14] Stiglitz, J. (2008) The Triumphant Return of John Maynard Keynes. Project Syndicate, 1 December. http://www.project-syndicate.org/commentary/stiglitz107

[15] Davar, E. (2014) How Flaws in the General Theory Render It Irrelevant to the Real World. Modern Economy, 5, 93-104. http://dx.doi.org/10.4236/me.2014.51011

[16] Davar, E. (2011) Flaws of Modern Economic Theory: The Origins of the Contemporary Financial-Economic Crisis. Modern Economy, 2, 25-30. http://dx.doi.org/10.4236/me.2011.21004

[17] Keynes, J.M. (1936-1960) The General Theory of Employment Interest and Money. Macmillan, London.

[18] Hansen, A.H. (1953) A Guide to Keynes. McGraw-Hill Book Company, New York.

[19] Harcourt, G.C. and Riach, P.A. (1997) The General Theory. 2nd Edition, Routledge, London.

[20] Hayes. M. (2010) The Economics of Keynes: A New Guide to the General Theory. Cheltenham and Northampton.

[21] Davar, E. (2013) Government Spending and Economic Growth. The Finance and Business, No. 2.

[22] Hoover, K.D., Weintraub, E.R. and Caldwell, B. (2009) John Maynard Keynes of Bloomsbury: Four Short Talks. 
Economic Research Initiatives at Duke (ERID) Research Paper No. 23.

[23] Kamiryo, H. (2012) Tax Policy Revisit to Two Multipliers, Tax and Government Spending, 1990-2010, in the Endogenous-Equilibrium, Using 72 Cases by Area and Country. Journal of Economic Sciences, 16, 65-87.

https://www.google.co.il/webhp? sourceid=chrome-instant\&ion=1\&espv=2\&ie $=\mathrm{UTF}-8 \# \mathrm{q}=\% 5 \mathrm{D}+\mathrm{Kamiryo} \% 2 \mathrm{C}+\mathrm{H} .+(2$ 012)+Tax+Policy+Revisit+to+Two+Multipliers $\% 2 \mathrm{C}+$ Tax + and + Government + Spending $\% 2 \mathrm{C}+1990 \% \mathrm{E} 2 \% 80 \% 932010$ $\underline{02 \mathrm{C}}$

[24] Marshall, A. (1930) The Pure Theory of Domestic Value. The London School of Economics, London.

[25] Hayek, F.A. (1931-1967) Prices and Production. Augustus M. Kelly Publishers, New York.

[26] Morishima, M. (1977) Walras' Economics. Cambridge University Press, Cambridge.

[27] Negishi, T. (1979) Microeconomic Foundations of Keynesian Macroeconomics. North-Holland, New York.

[28] Davar, E. (1994) The Renewal of Classical General Equilibrium Theory and Complete Input-Output System Models. Avebury, Aldershot, Brookfield USA, Hong Kong, Sydney.

[29] Davar, E. (2014) Walras and Contemporary Financial-Economic Crisis. Modern Economy, 5, 635-656. http://dx.doi.org/10.4236/me.2014.55060

[30] Patinkin, D. (1989) Money, Interest, and Prices. 2nd Edition, Abridged, The MIT Press, Cambridge.

[31] Lange, O. (1944) Price Flexibility and Employment. The Principia Press, Bloomington.

[32] Hahn, F.H. (1987) On Involuntary Unemployment. The Economic Journal, 97, 1-16. http://dx.doi.org/10.2307/3038226

[33] De Vroey, M. (2003) The History of Macroeconomics Viewed against the Background of the Marshall-Walras Divide. In: De Vroey, M. and Hoover, K., Eds., The IS-LM Model. Its Rise, Fall and Strange Persistence, Duke University Press, Durham.

[34] Chick, V. (1978) The Nature of the Keynesian Revolution: A Reassessment. Australian Economic Papers, 17, 1-20. http://dx.doi.org/10.1111/j.1467-8454.1978.tb00607.x

[35] Davar, E. (2015) Unemployment: Walras's Voluntary and Keynes's Involuntary. 8th International Conference of on Applied Economics in Economic Theory and Policy, Torun, 18-19 June 2015, 65-91.

[36] Shapiro, C. and Stiglitz, J.E. (1991) Equilibrium Unemployment as a Worker-Discipline Device. The American Economic Review, 74, 433-444.

[37] Meade, J. (1975) The Keynesian Revolution. In: Keynes, M., Ed., Essays on John Maynard Keynes, Cambridge University Press, Cambridge, 82-88.

[38] Walras, L. (1954) Elements of Pure Economics. Translated by W. Jaffe, Allen and Unwin, London.

[39] Schumpeter, J.A. (1954) History of Economic Analysis. Routledge, London.

[40] Chick, V. (1983) Macroeconomics after Keynes. A Reconsideration of the General Theory. The MIT Press, Cambridge, MA.

[41] Davidson, P. (2007) John Maynard Keynes. Palgrave, New York.

[42] Robinson, J. (1975) What Has Become of Keynesian Revolution? In: Keynes, M., Ed., Essays on John Maynard Keynes, Cambridge University Press, Cambridge, 123-131.

[43] Klein, L.R. (1952) The Keynesian Revolution. Macmillan Co. Ltd., London.

[44] Ahiakpor, J.C.W. (2001) On the Mythology of the Keynesian Multiplier: Unmasking the Myth and the Inadequacies of Some Earlier Criticisms. American Journal of Economics and Sociology, 60, 745-773. http://dx.doi.org/10.1111/1536-7150.00121

[45] Kahn, R. (1976) Unemployment as seen by the Keynesians. In: Worswick, G.D.N., Ed., The Concept and Measurement of Involuntary Unemployment, George Allen \& Unwin Ltd., London, 19-25.

[46] Boianovsky, M. and Trautwein, H.-M. (2003) Wicksell, Cassel and the Idea of Involuntary Unemployment. History of Political Economy, 35, 385-436. http://dx.doi.org/10.1215/00182702-35-3-385

[47] Darity Jr., W.A. and Horn, B.L. (1983) Involuntary Unemployment Reconsidered. Southern Economic Journal, 49, 717-733.

[48] Lerner, A.P. (1960) The Failure of the "New Economics" by Henry Hazlitt, Review. The Review of Economics and Statistics, 42, 234-235.

[49] McKenna, J.P. (1960) Review: The Failure of the New Economics. The American Economic Review, 50, 188-190.

[50] Varga, E. (1968) The Reason for the Popularity of Keynesians Theories. In Politico-Economic Problems of Capitalizm, Progress. 


\section{Appendix 1: The List of Books Related to Keynes's Theory Where Hazlitt's Name Is Not Mentioned}

Backhouse, R.E. and Batman, B.W. (2006) The Cambridge Companion to Keynes. Cambridge University Press, Cambridge. http://dx.doi.org/10.1017/CCOL0521840902

Backhouse, R.E. and Batman, B.W. (2011) Capitalist Revolutionary: John Maynard Keynes. Harvard University Press, Cambridge, MA. http://dx.doi.org/10.4159/harvard.9780674062849

Barnett, V. (2013) Keynes John Maynard. Routledge, NY

Bateman, B.W., Hirai, T. and Marcuzzo, M.C., Eds. (2010) The Return to Keynes. Harvard College, Cambridge, MA.

Clarke, P. (2009) Keynes: The Rise, Fall, and Return of the Twentieth Century's Most Influential Economist. Bloomsbury Press, New York.

Clarke, P. (2010) Keynes: The Twentieth Century's Most Influential Economist. Bloomsbury Press, London.

Davidson, P. (2007) Interpreting Keynes for the 21st Century. Palgrave Macmillan, New York. http://dx.doi.org/10.1057/9780230286559

Davidson, P. (2007) John Maynard Keynes. Palgrave, New York.

Davidson, P. (2009) The Keynes Solution. Palgrave Macmillan, New York.

De Vroey, M. (2004) Involuntary Unemployment: The Elusive Quest for a Theory. Routledge, London.

Dimand, R.W., Mundell, R.A. and Vercelli, A., Eds. (2010) Keynes's General Theory after Seventy Years. Palgrave Macmillan, New York.

Gnos, C. and Rochon, L.-P. (2008) The Keynesian Multiplier. Routledge, London.

Hayes. M. (2010) The Economics of Keynes: A New Guide to the General Theory. Cheltenham, UK and Northampton, MA.

Laidler, D. (1999) Fabricating the Keynesian Revolution. Cambridge University Press, Cambridge.

Lavoie, M. (2007) Introduction to Post-Keynesian Economics. Palgrave Macmillan, New York. http://dx.doi.org/10.1057/9780230626300

Leijonhufvud, A. (1968) On Keynesian Economics and the Economics of Keynes. Oxford University Press, New York. Moggridge, D. (1992) Maynard Keynes: An Economist Biography. Routledge, London.

Pasinetti, L.L. (2007) Keynes and Cambridge Keynesians. Cambridge University Press, Cambridge.

Patinkin, D. (1989) Money, Interest, and Prices. 2nd Edition, Abridged, The MIT Press, Cambridge.

Sheehan, B. (2009) Understanding Keynes's General Theory. Palgrave Macmillan, New York. http://dx.doi.org/10.1057/9780230232853

Skidelski, R. (1996) John Maynard Keynes. Macmillan, London.

Skidelski, R. (2009) Keynes: The Return of the Master. Public Affairs, New York.

Steele, G.R. (2003) Keynes and Hayek the Money Economy. Routledge, London. 